\title{
Şiî Ulemâya Yönelik Davet ve Fermanlar: Şehîd-i Evvel ve Ali el-Kerekî Örneği
}

\author{
Habib Kartaloğlu*
}

\section{Öz}

İslam coğrafyasının farklı bölgelerinde kurulan hanedanlıklar, siyasî merkezlerini ilim ve kültür havzasına dönüştürme gayretinde olmuşlardır. Yöneticilerin ilim ehlini desteklemelerinin ve onları hanedanlık merkezine davet etmelerinin muhtemel sebeplerden birisi de mezhebî tercihleridir. İran coğrafyasında hüküm sürmüş Serbedârîler (1337-1386) ve Safevîler (1501-1736), bu sebeple bölge dışındaki İmâmî ulemâyı İran'a göç etmeye teşvik etmişlerdir. Bu bağlamda Serbedârî Emîri Ali el-Müeyyed, Şehîd-i Evvel'e (ö. 786/1384) bir davet mektubu göndermiştir. Öte yandan Safevî hükümdarı Şah Tahmasb ise Ali el-Kerekî’yi (ö. 940/1534) İran'a davet için bir ferman yayınlamıştır. Şehîd-i Evvel, Serbedârî hükümdarının yapmış olduğu daveti kabul etmemekle beraber İmâmiyye fikhına dair yazmış olduğu el-Lüm'atü'd-Dımeşḳıyye adlı eserini göndermiştir. Öte yandan Şah Tahmasb'in resmî sahiplenmesiyle el-Kerekî, Safevî İran'indaki nüfûzunu pekiştirmiştir. Bu çalışmada öncelikli olarak Ali el-Müeyyed'in Şehîd-i Evvel'e gönderdiği mektup ele alınmakta ardından da Şah Tahmasb'in Ali elKerekî hakkında yayınlamış olduğu ferman ve el-Kerekî’nin Safevî yönetimiyle olan ilişkisi üzerinde durulmaktadır.

Anahtar Kelimeler: İslam Mezhepleri Tarihi, İmâmiyye, Şehîd-i Evvel, Ali elKerekî, Mektup/Ferman

Dr. Öğr. Üyesi, Sakarya Üniversitesi, İlahiyat Fakültesi, İslam Mezhepleri Tarihi Anabilim Dal1, hkartaloglu@sakarya.edu.tr, ORDIC: 0000-0003-4973-0787 


\title{
Invitation and Edicts Intended for the Shia Ulamā/ Sholars: The Example of Shahid al-Awwal and Ali al-Karakī
}

\author{
Habib Kartaloğlu*
}

\begin{abstract}
The dynasties that were established in different regions of the Islamic geography made efforts to turn their political centers into scientific and cultural centers. One of the possible reasons for the administrators to support the scholars and invite them to the dynasty center was their sectarian preferences. For this reason, the Sarbadars (1337-1386) and the Safavids (1501-1736) who reigned in Iran respectively, used to encourage the Imami scholars in the outside regions to migrate to Iran. In this context, the Sarbadar ruler Ali al-Mu'ayyad sent an invitation letter to Shahid alAwwal (d. 786/1384). On the other hand, the Safavid ruler Shah Tahmasb issued an edict to invite Ali al-Karaki (d. 940/1534) to Iran. Although Shahid al-Awwal did not accept the invitation of the Sarbadar ruler, he instead sent his book titled: al-Lum'a ad-Dimasqiya, which he wrote on the Imāmiyya fiqh. On the other hand, with the official appropriation of Shah Tahmasb, al-Qaraki reinforced his influence in Safavid Iran. In this study, firstly the letter that Ali Mu'ayyad sent to Shahid al-Awwal is dealt with, and then the edict issued to Ali al-Karakī by Shah Tahmasb as well as the relationship between al-Qaraki and Safavid administration is emphasized.
\end{abstract}

Keywords: History of Islamic Sects, Imāmiyya, Shahid al-Awwal, Ali al-Karakī, Letter/Edict

Asst. Prof., Sakarya University, Faculty of Theology, Department of History of Islamic Sects, hkartaloglu@sakarya.edu.tr, ORDIC: 0000-0003-4973-0787 


\section{Giriş}

İslam tarihinde merkezî otoritelerin zayıfladığı dönemlerde İslam coğrafyasının farklı bölgelerinde çeşitli hanedanlıklar ortaya çıkmıştır. Bölgesel hanedanlıkların kurulması her ne kadar siyasî istikrar ve birlik açısından olumsuz bir tablo oluşturmuş olsa da birden fazla idârî ve kültür merkezinin inşa edilmesine imkân sağlamıştır. Bunun sonucunda çeşitli bölgelerde kurulan hanedanlıklara başkentlik yapmış olan yerleşim yerleri, siyasî merkezler olmanın yanı sıra ilim ehlinin desteklendiği birer kültür merkezi haline gelmiştir. Örneğin İslam tarihinde Abbâsî devletinin zayıfladığı ve çeşitli hanedanlıkların ortaya çıktığı hicri dördüncü ve beşinci asırlar, ilim ehline çeşitli imkânların sağlandığı, önemli kaynak eserlerin telif edildiği ve İslam medeniyetinin zirveye ulaştı̆̆ 1 bir dönemdir. ${ }^{1}$ İbn Miskeveyh'in (ö. 421/1030) Büveyhî emirlerinden Adudüddevle'nin (367-372/978-983) ilim adamlarına sağladığı imkânlar ile ilgili vermiş olduğu şu bilgiler bunu açıklar niteliktedir: “...Fıkıhçılara, müfessirlere, kelâmcılara, hadisçilere, nesep bilginlerine, şairlere, nahivcilere, edebiyatçılara, tabiplere, müneccimlere, matematikçilere ve hendese âlimlerine maaş bağlandı. Adudüddevle, alanlarında ihtisas sahibi olanlara ve felsefecilere sarayındaki meclisine yakın bir yerde bulunan bir mekân tahsis etti. Böylece onlar burada toplumun aşağl kesiminden bilgisiz kimselerin baskı ve saldırılarından emin olarak karşılıklı görüşme ve ilmî tartışma yapma imkânına kavuştular. Ayrıca kendilerine maaş bağlandı ve çeşitli yardımlar yapıldı. Böylece bu ilimler ölü iken hayat buldular..."

Büveyhî emirlerinden Adudüddevle örneğinde olduğu gibi siyasî yöneticilerin ilim ehlini desteklemeleri ve onlara çeşitli imkânlar sağlamalarının arkasında, muhtemelen kendi entelektüel ilgileri ve siyasî rekabet içerisinde oldukları hanedanlıklara karşı nüfûz sahalarını genişletme düşüncesi yer almaktadır. Bu temel gerekçelerin yanı sıra özellikle mezhebî tercihlerinden dolayı bazı dönemlerde yöneticiler, farklı coğrafyalardaki kendi mezhebinden olan ulemâyı hanedanlık topraklarına davet etmişlerdir. Ör-

1 Ahmet Güner, "Büveyhî Devlet Adamlarının Kitaba İlgileri ve Kütüphaneleri”, Dokuz Eylül Üniversitesi Illahiyat Fakültesi Dergisi, no. 13 (2001): 36; Ahmet Güner, "Sâbûr b. Erdeşîr ve Dâru'l-İlm'i”, Dokuz Eylül Üniversitesi Illahiyat Fakültesi Dergisi, no. 13 (2001): 65 .

2 Ebû Ali Aḥmed b. Muhammed b. Yákûb İbn Miskeveyh, el-Kısmu'l-ahîr min kitâbi Tecâribi'l-ümem, c. 2 (Oxford: Basil Blackwell, 1921), 408. 
neğin İmâmiyye Şî̂liğini devletin resmi mezhebi olarak ilan ettiklerinde Safevîler, mezhebi tercihleri doğrultusunda kendilerine yardımcı olacak ve meşruiyet sahalarını genişletecek İmâmî ulemâdan yoksundular. Bu sebeple Safevîler, Şiî eğitimi sürdürmek ve toplumsal değişim-dönüşümü sağlamak maksadıyla İran dışındaki ulemâya yönelmek ve onları kendi topraklarına davet etmek zorunda kalmışlardır. ${ }^{3}$ İran coğrafyasında hüküm sürmüş Serbedârîler (1337-1386) ve ardından Safevîler (1501-1736), dinî ve siyâsî gerekçelerle, bölge dışındaki İmâmî ulemânın hanedanlık topraklarına gelmeleri için mektup göndermişler ve fermanlar yayınlamışlardır. Bu bağlamda bu çalışmada öncelikle Serbedârî Emîri Ali el-Müeyyed'in Şehîd-i Evvel'e (ö. 786/1384) gönderdiği mektup ele alınacak, ardından da Safevî hükümdarı Şah Tahmasb'nn (ö. 984/1576) Ali el-Kerekî (ö. 940/1534) hakkında yayınlamış olduğu fermanlar üzerinde durulacaktır.

\section{Serbedârîler ve Mezhebî Kimliğgi}

Serbedârîler, İlhanlı hükümdarı Bahadır Han'ın (ö. 736/1335) vâris b1rakmadan ${ }^{4}$ vefat etmesinin akabinde ortaya çıan siyasî istikrarsızlık ortamında İran'da teşekkül etmiş mahalli hanedanlardan biridir. ${ }^{5}$ Bir diğer ifadeyle Serbedârîler, XIV. yüzyılda Horasan bölgesinde yaşanan siyasî karmaşa ve ekonomik sıkıntılar ortamında çeşitli baskı ve

3 Dönemin önemli kaynakları arasında yer alan Aḥsenü't-tevârih'te Ḥasan Beg Rumlu (ö. 985/1577), Safevî devletinin kurulduğu dönemde bölgede İmâmiyye mezhebini öğretecek mezhebe mensup ulemânın ve Şiî kaynakların bölgede olmadığına dikkat çekmektedir. Bk. Ḥasan Beg Rumlu, Aḥsenü t-tevârîh (Tahran: Çâbhâne Ḥaydarî, 1357), 86.

4 Abdülkadir Yuvalı, “Ebû Said Bahadır Han”, Türkiye Diyanet Vakfi İslâm Ansiklopedisi (İstanbul: TDV Yayınlar1, 1994), 10:219.

5 Serbedârîler hakkında geniş bilgi için bk. Ġiyâseddîn b. Hümâmiddîn Hüseynî Hândmir, Târîhu habîbi's-siyer fi aḥbâri efrâdi beşer, c. 3 (Tahran: Kitabḥâne-i Hayyâm, 1333), 357-67; John Masson Smith, The History of the Sarbadâr Dynasty 1336-1381 A.D. And Its Sources (The Hague/Paris: Mouton, 1970); H. R. Roemer, "The Jalayirids, Muzaffarids and Sarbadars", The Cambridge History of Iran, ed. Peter Jackson ve Lawrence Lockhart, c. 6 (Cambridge: Cambridge University Press, 1986), 1-42; Yakûb Ajend, Klyâm-ı Şi î Serbedârân (Tahran: Neşr-i Göstere, 1363); Derya Coşkun, "Serbedârî Devletinin Siyasî, İçtimaî ve İktisadî Tarihi (1336-1382)" (Doktora Tezi, Atatürk Üniversitesi, 2016); Mustafa Şahin, Serbedârîler Darağacının Gölgesinde Kurulan Bir Devlet (İstanbul: İdeal Kültür Yayıncılık, 2017); V. F. Büchner, "Serbedârîler", MEB İslam Ansiklopedisi (İstanbul: Milli Eğitim Basımevi, 1988); Erdoğan Merçil, "Serbedârîler", Türkiye Diyanet Vakfi İslâm Ansiklopedisi (İstanbul: TDV Yayınları, 2009). 
adaletsizliklere maruz kalan kitlelerin bir tepki/başkaldırı hareketidir. Hândmîr'in belirttiğine göre "Serbedâr" ismi, dönemin yerel yöneticilerinin baskılarına maruz kalanları yanına çekerek isyan eden ve hanedanın kurucusu Abdürrezzâk b. Fazlullah Baştînî'nin "erkekçe başını darağacına vermek alçakça katledilmekten bin defa iyidir" (بردار ديدن هزار بار بهتر كه به نامردي به قتل رسيدن به مردي سر خود) sözünden hareketle verilmiştir. ${ }^{6}$ Serbedârîler hakkında bilgi veren bir diğer önemli kaynak olan Mirhând'ın Ravżâtü 's-ṣafâ adlı eserinde de benzer bilgiler verilmektedir. Mirhând, bu kelimeyi dönemin yöneticilerinin Horasan halkına karşı uyguladıkları baskılara ve adaletsizliklere karşı ayaklanarak gerekirse başlarını darağacına vereceklerini söyleyen bir grup insan için kullanmaktadır. ${ }^{7}$ Öte yandan İbn Battûta (ö. 770/1368-69) ise muhtemelen Serbedârîler'in ilk kuruldukları dönemde iktisâdî gereksinimlerden dolay1 liderleri Abdürrezzak ve taraftarlarının eylemlerini dikkate alarak yukarıda ifade edilenlerin aksine "karışıklık çıkaran", "yol kesen" ve "haraç alanlar" anlamında "serberdâr" kelimesine olumsuz bir anlam yüklemektedir. Ona göre bu tür eylemleri işleyen kişilere Irak’ta "şuttâr" Horasan bölgesinde "serberdar", Mağrib'te ise "sakûra" ismi verilmektedir."

Sosyal tabanını daha çok köylü ve çiftçilerin oluşturduğu bu isyan hareketinin organize olması ve alt yapısının sağlanmasında Şeyh Halife (ö. 736/1335) ve öğrencisi Şeyh Hasan el-Cûrî (ö. 743/1342)9 gibi dervişlerin ve mahalli fütüvvet teşkilatının katkıları olmuştur. ${ }^{10}$ Hanedanlığın ortaya çıkışında ve başarıya ulaşmasında rol üstlenen bu gruplar, etkinliklerini devletin kuruluşundan sonra da devam ettirmişlerdir. Devlet içerisindeki bu konumlarından ve rollerinden dolayı hanedanlıkta "Dervişler

6 Hândmir, Habîbü's-siyer, 3:358.

7 Seyyid Ḥamidüddin Muhammed b. Burhaneddin Hูandşah b. Kemaleddin Mîrhând, Târîh-i Ravżatü's-șafâ fì sîreti 'l-enbiyâ ve'l-mülûkve'l-h̆ulefâ, c. 5 (Tahran: Müessese-i Hayyâm ve İntişarât-1 Pîruz, t.y.), 601; Coşkun, "Serbedârî Devleti”, 13.

8 Ebû Abdullah Şemseddin Muhammed b. Abdullah İbn Battûta, İbn Battûta Seyahatnâmesi, çev. A. Sait Aykut, c. 1 (İstanbul: Yapı Kredi Yayınları, 2004), 559.

9 Hasan el-Cûrî hakkında detaylı bilgi için bk. Derya Coşkun, "XIV. Yüzyı1 Horasan'ında Şiî Bir Otorite: Şeyh Hasan Cevrî ve Siyaset Algısı", Türk Kültürü ve Hacı Bektaş Veli Araştırma Dergisi, no. 90 (2019): 65-76.

10 Smith, Sarbadâr Dynasty, 56-57; Muhammed Ḥüseyin el-Emânî, eş-Şehîdü'l-Evvel: Fakîhü 's-Serbedârân, çev. Kemâl es-Seyyîd (Kum: Müessese-i Enșâriyân, 1415/1995), 89; Coşkun, "Serbedârî Devleti", 110. 
ve Serbedârîler" şeklinde bir yapılanma sürekli var olmuştur. ${ }^{11}$ Bu ikili yapılanmanın kaçınılmaz bir sonucu olarak yaklaşık elli yıl hüküm süren Serbedârî idaresinde sürekli "yönetici-derviş" çekişmesi baş göstermiştir. ${ }^{12}$ Devletin kuruluşundan yıkılışına kadar devam eden bu ikili yapının siyasî idâre k1smında Emîr Abdürrezzâk (ö. 737/1337), Emîr Vecihüddîn Mesûd (ö. 745/1344), Hâce Ali Şemseddin(ö. 752/1351) ve Hâce Necmeddin Ali el-Müeyyed (ö. 788/1386) gibi önemli siyâsî liderler yer almıştır. Derviş ve fütüvvet teşkilatının yardımlarıyla teşekkül eden $^{13}$ Serbedârîlerin dervişler yapılanmasına ise Şeyh Halife, Hasan el-Cûrî, Derviş Aziz ve Derviş Rükneddîn gibi şahıslar liderlik yapmıştır. ${ }^{14}$ Muhtemelen bu ikili yapılanmadan dolayı Resul Ca'feriyân, Serbedârî hareketini aynı zamanda ŞeyhîŞiî devleti olarak da isimlendirmiştir. ${ }^{15}$

Serbedârîler' in siyasî yapılanması hakkında vermiş olduğumuz bu bilgilerden sonra onların mezhebî kimlikleri konusuna değinebiliriz. Zira yukarıda da ifade edildiği üzere Serbedârîler, kendi dönemlerinde yaşanan sosyal, ekonomik ve siyasî problemlere bir tepki hareketi olsa da hareketin alt yapısının sağlanması ve organize olmasında Şiîlik, tasavvuf ve mehdi anlayışının etkili olduğu ve hatta Şiîlikle ilgili görüşlerin daha ön planda olduğu görülmektedir. ${ }^{16}$ Hareketin Horasan bölgesindeki en eski Şiî yerleşim yerlerinden ve hatta bölgede Şiîlikten bahsedildiğinde Kum şehri ile birlikte anılan Beyhak'ta (Sebzevâr) ortaya çıkmış olması bunu destekler niteliktedir. ${ }^{17}$ Demir'in de ifade ettiği üzere Şiîliğin Beyhak bölgesine hangi kanalla ve ne zaman girdiğini tespit etmek oldukça güçtür. Ancak hicrî

11 Mîrhând, Târîh-i Ravżatü's-ṣafâ, 5:608; Coşkun, "Serbedârî Devleti”, 42.

12 Şahin, Serbedârîler Darağacının Gölgesinde Kurulan Bir Devlet, 472.

13 Said Amir Arjomand, The Shadow of God and The Hidden Imam (Chicago: The University of Chicago Press, 1984), 69.

14 Şahin Ahmetoğlu, "Serbedârî Hareketi ve Temel Görüşleri”, e-Makalat Mezhep Araştırmaları Dergisi 7, no. 1 (2014): 133.

15 Resul Cáferiyân, Târîh-i teşeyyú der Iran: ez ağaz tâ tulúu devleti Șafevî, 4. Bask1 (Tahran: Neşr-i İlm, 1390), 776.

16 Seyyid Ruhullah Perhizkârî, "Nakşşi Devlet-i Şî‘a Serbedârân-1 Horasân Der Göstereş-i Teşeyyu“ ve Temeddün-i İslâmî”, Pejûheşi Tarîh-i Ferheng ve Temeddün-i İslâmî 4, no. 13 (2014): 32.

17 Habip Demir, Horasan'da Şiilik: Iran'da Şiiliğin Tarihsel Kökleri (Ankara: OTTO, 2017), 178; Abbas İkbal Aştiyânî, Târîh-i Mog̉ol Ez Hamle-yi Çingîz tâ Teşkîl-i Devlet-i Tîmûrî (Tahran: Müessese-i İntişârât-1 Emîr Kebîr, 1384), 466; Enver Konukçu, "Beyhak", Türkiye Diyanet Vakfi İslâm Ansiklopedisi (İstanbul: TDV Yayınları, 1992), 6:58. 
beşinci asırdan itibaren Şiîliğin şehirde belirgin bir hale geldiğini ve bu özelliğiyle dönemin kaynaklarında yer aldığını söyleyebiliriz. ${ }^{18}$ Nitekim Abdülcelîl el-Ḳazvînî (ö. 560/1165'ten sonra), Sebzevâr hakkında şu ifadeleri kullanmaktadır: "Sebzevâr'a gelince orası Şîa ve İslam merkezidir. Güzel medreselerle ve nurlu mescitlerle donatılmıştır. Tarikat ve şeriat ögrenmiş seleflere halef olan âlimlerle doludur. Orada mülhitlere lanet ve Bâtinîlere husumet aşikârdır ve dersler, münazara meclisleri ve sürekli düzenlenen Kur'an hatimleri yapılmaktadır". ${ }^{19}$ Öte yandan Hamdullah el-Mustevfî̀ ve İbn Battûta'nın vermiş olduğu bilgilerde Beyhak halkının ve dolayısıyla Serbedârîlerin mezhebî kimliği açıklar niteliktedir. Nitekim el-Müstevfî, Beyhak halkının İsnâ Aşeriyye mezhebine mensup olduklarını ifade ederken İbn Battûta, Serbedârîlerin hepsinin Rafizî inancını benimsediklerini dile getirmektedir. Hatta ona göre Rafîzî mezhebinden olan Serbedârîler, Horasan bölgesinde ikamet eden Ehl-i sünnet ahaliyi bask1 yoluyla kendi mezheplerine sokmaya girişmişlerdir. ${ }^{20}$

Beyhak bölgesi ve dolayısıyla Serbedârîlerin sosyal tabanını oluşturan kitleler hakkında verilen bu bilgiler, bir taraftan Serbedârîlerin mezhebi kimliklerini diğer taraftan da onların isyan etme ve devletleşme sürecinde en önemli unsurunun Şî̂lik olduğunu ortaya koymaktadır. ${ }^{21}$ Zira Serbedârîler, organize olma ve teşkilatlanma sürecinde Gâib İmam'ın zuhuru/mehdilik anlayışını ön plana çıkarmışlardır. Hatta bu politik yapılanmada söz konusu mehdeviyet anlayışı, rasyonel İmâmî fikıh ve kelâmın ön plana ç1karıldı $\breve{g}_{12}{ }^{22}$ Serbedârîlerin son yıllarında dahi devam ettirilmiştir. Nitekim kaynaklarda Ali el-Müeyyed'in her gün bir atı hazırlatarak İmam Mehdî için beklettiği nakledilmektedir. Öte yandan hareketin Şiîlikle olan bağlantısını gösteren bir diğer delil de Serbedârî yöneticilerinin emriyle basılan paralarda On iki imamın adının yazılmış olmasıdır. Aşağıda da belirtileceği üzere Serbedârîlerin mezhebi eğilimlerini ortaya koyan daha da önemli

18 Demir, Horasan'da Şiilik, 180-81.

19 Abdülcelîl el-Kazvinî, Kitâbü'n-Naḳd: Ba'du meśâlibi’n-nevâșib fî naḳdi ba'du fệ̣̂hịi'r-revâfiż (Tahran: Encümeni Așârı Millî, 1358), 202.

20 Hamd-Allah Mustawfi Kazvînî, Nuzhat-al-Kulûb, çev. G. Le Strang (London: Brill, 1919), 148; Battûta, Seyahatnâme, 1:559.

21 İbni Arabşah, Acaibu'l Makdur (Bozkırdan Gelen Bela), çev. Ahsen Batur (İstanbul: Selenge Yayınları, 2012), 65.

22 Arjomand, The Shadow of God, 69; Hanifi Şahin, İhanlılar Döneminde Şiilik (İstanbul: Ötüken Neşriyat, 2010), 237-38. 
delil, Ali el-Müeyyed'in dinî ve siyâsî gerekçelerle bölge dişındaki İmâmî ulemâyla temasa geçmesi ve onları İran'a davet etmesidir. ${ }^{23}$

\section{Serbedârî Emîri Ali el-Müeyyed'in Şehîd-i Evvel'e Gönderdiği Mektup}

\subsection{Ali el-Müeyyed'in Şehîd-i Evvel-i Davet Etme Gerekçesi}

On iki imam adına para bastırıp Şiîliği devletin resmi mezhebi haline getirmek isteyen Ali el-Müeyyed, ${ }^{24}$ Şeyh Hasan el-Cûrî taraftarlarının mehdî ${ }^{25}$ anlayışı etrafında oluşturdukları aşırı fikirlere karşı rasyonel İmâmî düşünceyi topluma hâkim k1lma gayreti içerisindeydi. ${ }^{26}$ Ancak Serbedârîler, uzun zamandır Sünnî iktidarların kontrolündeki İran coğrafyasında (Beyhak/ Sebzevâr) ortaya çıkmış olduklarından İmâmî fıkhını uygulayacak ve onun tedrisini yapacak nitelikli ulemâdan yoksundular. Böyle bir coğrafyada yeni bir dinî/siyasî zemin oluşturmak istenildiğinde kendilerine yardımcı olacak bölge dışındaki ulemâya yönelmek kaçınılmaz gözükmektedir. Nitekim böyle bir yolu tercih eden Ali el-Müeyyed, bu gerçeği “biz aramızda fetvasına itimat edilebilecek veya halkımızın doğru yolu ve inançları öğrenebilecekleri kimseyi bulamıyoruz.... vatanımızın liderinin ve rehberinin olmaması sebebiyle Allah'ın gazabına uğrayacă̆ı endişesi içerisindeyiz '27 ifadeleriyle Şehîd-i Evvel'e gönderdiği mektupta dile getirmektedir. Ayr1ca Serbedârîlerden yaklaşık bir buçuk asır sonra kurulan Safevîler'de de benzer bir durumla karşılaşmışlardır. Nitekim İmamiyye'yi devletin resmi mezhebi olarak ilan eden Şah İsmâil'in mezhebin propagandasını yapacak

23 Mîrhând, Târîh-i Ravizatü's-șafâ, 5:524; Hândmir, Habîbü s-siyer, 3:366; Aștiyânî, Târîh-i Mogol, 466; Smith, Sarbadâr Dynasty, 55-60; Mehdî Ferhâni Münferid, Muhâceret-i ulemâ-yı Şîa ez Cebel-i Âmil be Iran Der Așr-l Șafevi (Tahran: Müessese-i İntişârât-1 Emîr Kebîr, 1396), 69; Shivan Mahendrarajah, "The Sarbadars of Sabzavar: Re-Examining Their 'Shi'a' Roots and Alleged Goal to 'Destroy Khurasanian Sunnism”, Journal of Shi 'a Islamic Studies 5, no. 4 (2012): 394.

24 Mîrhând, Târîh-i Ravżatü's-ṣafâ, 5:624; Hândmir, Habîbü's-siyer, 3:366; Ajend, Serbedârân, 197; Cáferiyân, Târîh-i teşeyyú der İan, 781.

25 Smith, Sarbadâr Dynasty, 56; Şahin, Serbedârîler Darağacının Gölgesinde Kurulan Bir Devlet, 309.

26 Arjomand, The Shadow of God, 70; Stefan Winter, "Shams al-Din Muhammad ibn Makki 'al-Shahid al-Awwal' (d. 1384) and the Shi'ah of Syria", Mamluk Studies Review 3 (1999): 162-63.

27 Ajend, Serbedârân, 199; el-Emânî, eş-Şehîdü'l-Evvel, 86. 
İmâmî ulemâyı ve Şiî kaynakları bölgede bulamadığını Ḥasan Beg Rumlu açık ifadelerle ortaya koymaktadır. ${ }^{28}$

Ali el-Müeyyed'in bölge dışındaki ulemâya yönelmesinin arkasındaki bir diğer önemli gerekçe de devlet yönetimine sürekli müdahale eden Şeyh Hasan el-Cûrî taraftarı dervişlerin gücünü tamamen bertaraf etmek istemesidir. ${ }^{29}$ Serbedârîlerin kuruluşunda etkin olan dervişler, kendi anlayışları doğrultusunda bir idare kurmak için sürekli siyâsî eylemlerde bulunmuşlardır. ${ }^{30}$ Serbedârî yöneticiler, iktidara geliş sürecinde dervişlerin desteğini almış olmalarına rağmen kısa zaman içerisinde dervişlerle başa çıkmak zorunda kaldılar. Nitekim Serbedârî idaresinde sürekli yaşanan "yönetici-derviş" çekişmesinin son örneklerinden biri de Ali el-Müeyyed zamanında isyan eden Derviş Azîz ve Derviş Rukneddin isyanlarıdır. Hatta Derviş Rukneddin kendi düşünceleri doğrultusunda bir idare kurmak için Sebzevâr'1 ele geçirdi ${ }^{31}$. Dervişlerin artan etkisiyle mücadele etmek zorunda kalan ${ }^{32}$ Ali el-Müeyyed, bir taraftan siyâsî ittifaklar yaparken diğer taraftan da dervişlerin aşırı fikirleri karşısında daha 1lımlı anlayışı hâkim kılma içerisine girmiştir. O, Emir Velî ile yaptığ 1 ittifak sonucunda Sebzevar'ın kontrolünü tekrar sağladığında dervişlerin artan etkisini kırmak için Şeyh Hasan Cûrî’nin taraftarını ziyaretgâh olarak kabul ettikleri mezarları dağıttırıp yerlerinin çöplüğe çevrilmesini emretmiştir. ${ }^{33}$ Dolayısıyla Ali elMüeyyed'in Şehîd-i Evvel'e mektup göndermesinin arka planında İmâmî fikhını uygulayacak ulemânın bölgede bulunmaması ve siyâsî mücadeleye giriştiği dervişlerin eylemlerine karşılık vermek ve onların halk üzerindeki gücünü kırmak istemesi yer almaktadır.

\footnotetext{
Rumlu, Ahsenü t-tevârîh, 86.

Ajend, Serbedârân, 197.

Şahin, Serbedârîler Darağacının Gölgesinde Kurulan Bir Devlet, 309, 405.

Hândmir, Habîbü 's-siyer, 3:366.

Smith, Sarbadâr Dynasty, 60; Arjomand, The Shadow of God, 70.

Mîrhând, Târîh-i Ravżatü's-șafâ, 5:624; Hândmir, Habîbü's-siyer, 3:366.
} 


\section{2. Şehîd-i Evvel'e Gönderilen Mektup}

Ali el-Müeyyed, dinî ve siyâsî gerekçelerle Cebel-i Âmil bölgesi ulemâsından Şehîd-i Evvel Muhammed b. Mekkî’yle ${ }^{34}$ irtibata geçti. O, Şehîd-i Evvel'i Sebzevar'a davet etmek için yakın adamlarından Şemseddin Muhammed el-Âvî’yle bir mektup gönderdi. Tespit edilebildiği kadarıyla ilk defa kısaca Allâme el-Tüsterî $\hat{1}^{35}$ tarafından bahsedilen ancak daha sonraki kaynaklarda tam metninin yer aldığı mektup şu şekildedir:

"Güzel kokusunu yayan, geçtiği yerlerde kokusunu arkasinda bırakan amberin güzel koku yaymast gibi bir selam. Dolunayla her durumdayken mukabele eden bir selam. Her sabah güneşiyle eşdeğerde olan bir selam. Her zaman gayretli çalışmalarıyla ilim talep etme ve ilimden faydalanan hakiki din güneşine selam.

Irade sahibi ve makamı yüce, âlim, vazife-şinâs, fazilet sahibi, övülmüs özelliklere sahip muttaki, temiz soylu zamanın allâmesi, milletlerin rehberi, derinlik sahibi âlimlerin örneği, faziletli muhakkiklerin tâbi olduğu, firkaların ve tarikatların açılklayıcısı, İslam ölçütleri içinde sorunları halleden, çeşitli faziletler, ilim ve hünerleri daha ileri seviyeye taşıyan, Peygamberlerin vârisi, İmamların adetlerini ihya eden, Mevla 'mızın mübarek huzuruna;

Allah'ın yeryüzüne koyduğu sir, Hz. Muhammed ve Ehl-i beyti hürmetine sonsuz nimetleri ve sa yini kendi devletinin üzerine açan doğru dinin güneşi olan önderimiz! Size muhabbet besleyen sizin hayraniniz olan ben, sizi görmeyi sonsuz bir derecede arzulamaktayım. Arzum budur ki bu ayrılığın ardından sizi ziyaret etmeğe müşerref olayım. Görüss sahiplerinin mercii konumunda bulunan siz zât-ı âlilerin makamına arz ederim ki Horasan Şî̀leri - Allah onları muhafaza etsin- sizi görmeye ve sizin fazilet deryanizdan ve ilminizden feyz alarak görmeye hasrettirler. Bu diyarın ilim sahipleri zamanın kötülüğ̈̈nden çoğu veya tamamı darmadağınlk olmuşlardır. Emîü’l-müminîn "âlimlerin ölümleriyle dinde gedik açılır" demektedir. Biz aramızda fetvasina ilmî açıdan itimat edilebilecek ya da halkımızın doğru yolu ve inançları

34 Şehîd-i Evvel için bk. Muhammed b. Hasan el-Hür el-Âmilî, Emelü'l-Âmil, c. 1 (Bag̉dât: Mektebetü'l-Endülüs, ts.), 181-83; Yûsuf b. Aḥmed el-Bahrânî, Lü'lüetü'lbaḥreyn fi'l-icâzât ve terâcimü ricâli'l-hadîs (Baḥreyn: Mektebetü'l-Fahravî, 1429), 138-43; Mirza Abdullah Efendi el-İsbahânî, Riyâzzü'l- 'ulemâ ve hìyâzü'l-fudelâ, c. 5 (Kum: Matba'atü'l-Hुayyâm, 1401), 184-91.

35 Kâḍ̂i Nûrullah el-Mer'aşî et-Tüsterî, Mecâlisü'l-mü'minîn, c. 3 (b. y.: Dârü Hişâm, 1439/2017), 449. 
ondan ögrenebilecekleri kimseyi bulamıyoruz. Allah'tan niyaz ediyoruz ki zât-ı âlileriniz bizlerin yanında bulunur ve üzerimize nur saçarsın ki ilmini takip edelim ve senin usulünü kendimize rehber edinelim. Büyüklüğ̈̈nüz ve cömertliğinizin âlemde bilindiğini, kerametinizin her bölgeye yayılmış olduğunu bilmekteyiz. Iyi niyetli rica ve hacet, kerîm dergâha götürüldüğ̈̈nde yerine getirileceğine inandı̆̆ımızdan ümit ederiz ki ricamız ve arzumuza icabet edilir.

Allah Teâlâ, "ve onlar ki Allah ın gözetilmesini emrettiği şeyi (akrabalar ve müminler arasında olması gereken bă̆l) gözetirler..." [er-Ra'd, 13/21] buyurmaktadır. Hiç şüphesiz aramızda akrabalık bă̆l vardır. $O$ da Íslâm'ın getirdiği manevi bir bă̆dır. Korunması gereken bă̆lılığın en önemli olanı iman bağıdır. Ondan sonra bedensel ve akrabalık kan bă̆g gelir. Bu iki bă̆ zamanın akışı ve dünyadaki hâdiseler birbirinden ayıramaz. Bu ikisi firtınaların bile yıkamadığı iki kayadır. Bizim vatanımızın liderinin ve rehberinin olmamasi sebebiyle Allah'in gazabina uğrayacă̆l endişesi içerisindeyiz. Her vakit lütfedip Allah'a tevekkül ederek bir mazeret göstermeksizin buraya teşrif ederseniz çok fazla ihsanla karşılaşacaksınız. Elhamdülillah sizin değerinizi biliyoruz. Ve inşallah hakkınızı tanıyıp sizi değerli kılacă̆ız. Sizin beğenilmiş temiz hasletlerinizden dolayı ümit ediyoruz ki bu kadar ısrarcı olmamızı affeder ve sözü bu kadar uzatmamızı bağışlarsınız. Selam Íslam milletinin üzerine olsun.

Seni seven ve sana hayranlık duyan Ali el-Müeyyed"'36

\subsection{Mektubun Gönderiliş Tarihi ve Şehîd-i Evvel'in Mektuba Verdiği Cevap}

Şehîd-i Evvel'e gönderilen mektubun gönderiliş tarihini tam olarak tespit etmek mümkün değildir. Büyük bir ihtimalle mektup, Emîr Timur'un Serbedârî merkezi Sebzevar'1 tamamen ele geçirdiği 784/1383 tarihinden önce ve Ali el-Müeyyed'in Derviş Rukneddin isyanının bastırıldığ 780/1379 tarihinden bir süre sonra gönderilmiştir. ${ }^{37}$ el-Hürr el-Âmilî’ye göre, el-Lüm ' $a$ 'yı Şehîd-i Evvel (ö. 786/1384) idam edilmezden önce tu-

\footnotetext{
36 Ajend, Serbedârân, 199-200; el-Emânî, eş-Şehîdü'l-Evvel, 85-87; Aḥmed el-Kâtib, Şiada Siyasal Düşüncenin Gelişimi, çev. Mehmet Yolcu (Ankara: Kitâbiyât, 2005), 419-20; Coşkun, "Serbedârî Devleti", 90-91.

37 Mahendrarajah, "The Sarbadars of Sabzavar", 395.
} 
tuklandığı esnada yedi günde yazmıştır. ${ }^{38}$ Şehîd-i Sânî ise el-Lüm 'a'ya yazdığ 1 şerhte, söz konusu eserin 782 tarihinde kaleme alındığını ifade etmektedir. ${ }^{39}$ Şehîd-i Evvel'in öğrencilerin Ali b. Hâzin el-Hâirî'ye 1384 tarihinde vermiş olduğu icâzette bu eserin yer alıyor olması Şehîd-i Sânî'nin vermiş olduğu tarihi destekler niteliktedir. ${ }^{40}$ Ayrıca Abdullah Efendi de eserin hapiste yazıldığı bilgisinin doğru olmadığını veyahut Şehîd-i Evvel'in idam edilmezden önceki hapse atılmasının dışında farklı bir zamandaki tutuklanması olabileceğini belirtmektedir. ${ }^{41}$ Şehîd-i Evvel, el-Lüm 'a' yı Ali el-Müeyyed için kaleme aldığına göre söz konusu mektubun da Şehîd esSânî’nin belirttiği tarihten önce; Derviş Rukneddîn isyânının bastırıldığ 780/1379 tarihten sonraki bir zamanda kaleme alındığını söyleyebiliriz.

Şehîd-i Evvel, Ali el-Müeyyed'in Serbedârî topraklarına yapmış olduğu daveti kabul etmemekle beraber, İmâmiyye fikhına dair yazmış olduğu elLüm 'atü'd-Dımeşkıyye adlı eserini elçi Şemseddin el-Âvî ile Horasan'a gönderir. ${ }^{42}$ Şehîd-i Evvel'in bu mektup öncesinde de Ali el-Müeyyed'le iyi ilişkiler kurduğu ve Irak'ta bulunduğu esnada birbirleriyle mektupla haberleştikleri anlaşılmaktadır. ${ }^{43}$ Ancak Şehîd-i Evvel'in özür beyan ederek davete icabet etmemesinin gerekçesi konusunda bir belirsizlik bulunmaktadır. Nitekim el-Kâtib, Şehîd-i Evvel'in Ali el-Müeyyed'in "dinî merciyyet olma" teklifini reddetme gerekçesinin açık olmadığını belirtmektedir. Çünkü davete olumlu cevap vermemesinin arkasında onun Serbedârî yönetimine bakışı, Ali el-Müeyyed'in samimi olup olmadığı, Serbedârî yönetiminde üstleneceği rol konusundaki belirsizlik veya bunların dişında daha özel bir sebebin olup olmadığı konusunda bir belirsizlik bulunmaktadır. ${ }^{44}$ Bununla birlikte Mazzaoui, Şehîd-i Evvel'in Dımaşk'ta kendisine yönelik

\footnotetext{
38 Âmilî, Emelü'l-Âmil, 1:183.

39 Zeynüddîn b. Ali el-Âmilî Şehîd-i Sânî, er-Ravżatü'l-behiyye fî şerhi Lüm 'ati'dDimaşkıyye, 2. Basl1, c. 1 (Kum: Çâbhâne-i Emîr, 1398), 239; Cáferiyân, Târîh-i teşeyyu der Iran, 781; Ali Hakan Çavuşoğlu, "Şehîd-i Evvel", Türkiye Diyanet Vakfi İslâm Ansiklopedisi (İstanbul: TDV Yayınları, 2010), 38:438.

40 Muhammed Bâḳır el-Meclîsî, Bihârü'l-envâr li düreri ahbâri'l-eimmeti'l-ethâr, 2. Bask1, c. 104 (Beyrût: Müessetü'l-Vefâ, 1983), 186-92.

${ }^{41}$ Mîrza Abdullah Efendi el-İșbahânî, Tálîkatü Emeli'l-âmil (Mektebetü Ayetullah elMar'aşi, 1410), 77; el-İsbahânî, Riyâzü 'l- 'ulemâ, 1401, 5:190.

42 Tüsterî, Mecâlisü'l-mü'minîn, 3:449; el-İșbahânî, Tálîkatü Emeli'l-âmil, 77.

43 Sânî, er-Ravżatü'l-behiyye, 1:239.

44 Kâtib, Şiada siyasal düşüncenin gelişimi, 421.
} 
suçlamalarla mücadele etmek zorunda kaldığından dolayı davete icabet edemediğini dile getirmektedir. ${ }^{45}$ Muhtemelen Mazzaoui, Şehîd-i Evvel'in ömrünün sonlarına doğru Dımaşk'ta yaşadığı olaylar, hapsedilmesi ve nihayetinde öldürülmesini dikkate alarak ${ }^{46}$ bu şekilde bir gerekçe öne sürmektedir.

\section{4. Şah Tahmasb'ın Ali el-Kerekî Hakkında Yayınladığı Ferman}

\subsection{Safevî Devletinin Ulemâ İthal Etme Gerekçesi}

Safevî devletinin kurulmasında asıl unsuru oluşturan Erdebil tekkesine bağlı Türkmenler, ${ }^{47}$ İmâmiyye Şiiliğinin dışında senkretik karakterli bir inanca sahiptiler. ${ }^{48} \mathrm{Bu}$ inanca göre şah, tanrının tecellisi ve beklenen mehdidir. ${ }^{49}$ Ancak 1501 tarihinde Tebriz'de şahlığını ilan eden Şah İsmâil, hutbeyi on iki imam adına okutarak yeni kurulan devletin mezhebinin İmâmiyye olduğunu ilan etmiştir. ${ }^{50}$ Devletin yapılanmasındaki bu tercih sonucunda Safevîler bir anlamda uzun süre Sünnî iktidarların kontrolündeki bölgenin mevcut birikiminden istifade imkânını yitirmişlerdir. ${ }^{51}$ Ḥasan Beg Rumlu, Safevîlerin mezhebi tercihleri doğrultusunda yaşadıklarını şöyle ifade etmektedir: "O vakit insanlar Ca'ferî mezhebinin esaslarını İsnâaşeriyye'nin kanunlarını bilmiyorlardı. Zira İmâmiyye mezhebine ait fikıh kitaplarından biri yoktu. Şerîat penâh Gâzî Nașrullah Zeytûnî'nin elinde bulundurduğu Sultânu'l-ulemâ el-Mütebahhirîn Şeyh Cemâlüddîn el-Hillî̀nin telif ettiği Kâvâidü'l-İslâm adlı eserinin birinci cildi ile dinî konularda eğitim veriliyordu. Gün geçtikçe İsnâaşeriyye mezhebinin hakikat güneşi yükselmeye başladı". ${ }^{52}$ Rumlu'nun bu pasajına doğrudan

45 Michel M. Mazzaoui, The Origins of the Safawids: Shi ism, Sufism and the Ghulat (Wiesbaden: Franz Steiner Verlag, 1972), 67.

46 Âmilî, Emelü'l-Âmil, 1:183; el-İsbahânî, Riyâzü 'l- 'ulemâ, 1401, 5:186,189; Çavuşoğlu, "Şehîd-i Evvel", 438-39.

47 Faruk Sümer, Safevi Devletinin Kuruluşu ve Gelişmesinde Anadolu Türkleri (Ankara: Selçuklu Tarih ve Medeniyeti Enstitüsü Yayınları, 1976), 22.

48 Mehmet Çelenk, 16-17. Yüzyıllarda Iran'da Şiîliğin Seyri, 2. Baskı (Bursa: Emin Yayınları, 2016), 253.

49 Arjomand, The Shadow of God, 69-70.

50 Rumlu, Ahsenü t-tevârîh, 85-86.

51 Çelenk, İran'da Şî̀liğin Seyri, 256.

52 Rumlu, Ahsenü 't-tevârîh, 86. 
alıntı yapan veya buraya atıfta bulunan araştırmacılar, Safevîler'in İmâmî ulemânın ve Şiî kaynakların yetersizliği sebebiyle özellikle Cebel-i Âmil bölgesindeki İmâmî âlimlere yöneldiklerini ifade etmektedirler. ${ }^{53}$ Araştırmacıların kahir ekseriyetinin kabul ettiği teze göre, toplumsal dönüşüm sürecinde kendilerine yardımcı olacak bir ilmiye sınıfı oluşturmak zorunda kalan Safevîler, bölge dişındaki ulemâyı İran'a davet ettiler ve birçok Arap İmâmî âlim de bu davete icâbet ettiler. ${ }^{54}$ Bununla birlikte konu hakkında araştırmaları bulunan Hourani, Arjomand ve Abisaab, Safevîler'in Şiî ulemâyı davet etme gerekçesinin yegâne sebebinin bölgede Şiî âlimlerin bulunmaması olmadığını söylemektedirler. Hourani, Safevîler'in İmâmî ulemâyı davet etmelerinin arkasında bölgedeki nüfûz sahibi kişilerle bağlantısı olmayan ve kaynaklardan hüküm çıkarmayı önemseyen ulemânın hanedanlıkta istihdam edilmesinin devletin geleceği ve siyâsî meşrutiyeti için daha fazla fayda sağlayacağı düşüncesinin etkin olduğu kanaatindedir. ${ }^{55}$ Aynı şekilde Arjomand ve Abisaab'a göre de Safevîler'in bölge dışındaki ulemâyı hanedanlıkta önemli dinî görevlere getirmeleri kendileri için daha tercih edilebilir bir durumdur. Zira Arap coğrafyasındaki İmâmî ulemâ, İran'da ikâmet edenlerden belirgin bir şekilde farklıydılar ve herhangi bir siyasi grup veya etnik sinıfla finansal ve idari münasebetleri bulunmamaktayd $1 .{ }^{56}$ Sonuç olarak Safevîler'in mezhebî tercihlerinden dolayı toplumsal değişim ve dönüşüm sürecinde yeni bir ulemâ sınıfı oluşturmak için zarûreten bölge dışındaki ulemâya yöneldikleri tezi daha fazla kabul görmektedir. Bununla birlikte bazı çalışmalarda ise Safevîler'in

53 Edward Granwille Browne, A Literary History of Persia, 5. Bask1, c. 4 (Cambridge: The Cambridge University Press, 1959), 54-55, 360; J. Aubin, "Sāh Ismāil et Les Notables de l'Iraq Persan", Journal of the Economic and Social History of the Orient 2, no. 1 (1959): 53; Mazzaoui, The Origins of the Safawids, 6; Moojan Momen, An Introduction to Shii Islam (New Haven and London: Yale University Press, 1985), 108; Cafer el-Muhâcir, el-Hicretü' 'l-Âmiliyye ilâ İrân fi 'l-așri 's-Safevî (Beyrût: Dârü'rRaḍ̂â, 1989), 221.

54 Andrew J. Newman, "The Myth of the Clerical Migration to Safavid Iran", Die Welt des Islams, no. 33 (1993): 66.

55 Albert Hourani, "From Jabal 'Amil to Persia", Bulletin of the School of Oriental and African Studies, no. 49 (1986): 137.

56 Arjomand, The Shadow of God, 129; Rula Jurdi Abisaab, "The Ulama of Jabal 'Amil in Safavid Iran, 1501-1736: Marginality, Migration and Social Change”, Iranian Studies 27, no. 1 (1994): 113-14; Rula Jurdi Abisaab, "History and Self-Image: The Amilis and Their Clerics in Syria and Iran (Fourteenth to Sixteenth Centuries)", Distant Relations: Iran and Lebanon in the Last 500 Years, ed. H. E. Chehabi (London: I.B.Tauris, 2006), 74-75. 
hânedanlığın geleceği ve meşruiyeti için tercihen bölge dışındaki ulemâya yöneldiklerini dile getirilmektedir. ${ }^{57}$

\subsection{Ali el-Kerekî ve Şafevî Yönetimiyle Olan İlişkileri}

İmâmiyye'nin devletin resmi mezhebi olarak kabul edilmesiyle başlayan radikal değişim sürecinde Safevîler, toplumsal tabanda Şiîliğin yayılması için bizzat ulemâya fermanlar göndermiştir. Safevî topraklarına davet edilen ulemâ, esas itibariyle kendi nitelikleri doğrultusunda görevlendirildiler. Bununla birlikte davet edilen ulemâdan bazıları siyâsî/idârî görevlere getirilerek devlete meşruiyet kazandırma sürecinin bir parçası haline geldiler. ${ }^{58}$ Nitekim özellikle haraç ve Cuma konusundaki görüşleriyle el-Kerekî (ö. 1534/940), Safevî kimliğinin ortaya konulması ve devletin desteklenmesi için dinî birikimini açıkça ortaya koydu. ${ }^{59}$

Aslen Kerekînûhlu olan Muhakkık-1 Sânî Ali el-Kerekî, ${ }^{60}$ Cebel-i Âmil ulemâsının Safevî yönetimiyle kurulan ilişkisinde önemli bir yere sahiptir. ${ }^{61}$ Newman, Safevî İran'a bölge dişındaki İmâmî ulemânın göç ettiği ve Safevî idaresinde önemli görevler üstlendikleri tezine karşı çıkmış olmasına rağmen el-Kerekî’nin bunun istisnâsı olduğunu kabul etmektedir. ${ }^{62}$ el-Kerekî, Safevî devletinin kurulmasından kısa bir süre sonra Safevî yö-

57 Habib Kartaloğlu, “Batılı Araştırmacılara Göre Safevi İran’a Şiî Ulemâ Göçü”, Turkish Journal of Shiite Studies 1, no. 1 (2019): 28-42.

58 Çelenk, Iran'da Şiîliğin Seyri, 276.

59 Newman, "The Myth of the Clerical Migration", 79; Hourani, "From Jabal 'Amil to Persia", 137.

60 Âmilî, Emelü'l-Âmil, 1:121-22; el-Bahrânî, Lü'lüetü'l-bahreyn, 146-54; Mirza Abdullah Efendi el-İsbahânî, Riyâzü'l-'ulemâ ve hiyâzżu'l-fudelâ, c. 3 (Kum: Matba'atü'l-Ḩayyâm, 1401), 441-60.

${ }^{61}$ el-Muhâcir, el-Hicretü'l-Âmiliyye ilâ İân, 221; Devin J. Stewart, "Notes on the Migration of Āmilī Scholars to Safavid Iran", Journal of Near Eastern Studies 55, no. 2 (1996): 81-82, 95.

62 Müstakil olarak çalışılması gereken el-Kerekî ile el-Kâtifî arasındaki tartışmalar için bk. Said Amir Arjomand, "The Mujtahid of the Age and the Mulla-bashi: An Intermediate Stage in the Institutionalization of Religious Authority in Shi'ite Iran", Authority and Political Culture in Shi'ism, ed. Said Amir Arjomand (Albany: State University of New York, 1988), 81; Newman, "The Myth of the Clerical Migration", 67,78; Stewart, "Notes on the Migration of Āmilī Scholars", 82; Mazlum Uyar, Şi Ulemanın Otoritesinin Temelleri (İstanbul: Kaknüs Yayınları, 2004), 130-34. 
netimiyle irtibâta geçmiş ${ }^{63}$ ve Safevîler'in 908/1503 tarihinde Kâşân'1 ele geçirmelerinde hazır bulunmuştur. Daha sonra Safevî yönetiminden çeşitli destekler alarak Necef'e yerleşen el-Kerekî,${ }^{64}$ Şah İsmâil'den sonra Şah Tahmasb zamanında da Safevîlerle irtibatını devam ettirmiştir. O özellikle Risâle fì șalâti'l-cum 'a, Kâatı 'atü'l-lecâc fì hilli'l-harâc ve Risâletü Nefehâti'l-lâhût fì la 'ni'l-cibt ve't-tầĝt adlı eserlerinde dile getirdiği görüşlerle İmâmî ulemânın mevcut yönetimlerle olan ilişkilerinin yeniden düzenlenmesinin önünü açmıştır. Zira o, sebbü's sahabe uygulamalarının caiz olduğunu savunmanın yanı sıra müctehidin kıldırması şartıyla gaybet döneminde Cuma namazı kılınabileceğini ve devlet başkanının haraç arazilerinden vereceği tahsisâtı almanın câiz olduğunu savunmaktadır. Bu görüşlerinden dolayı birçok Şiî âlim -özellikle de İbrâhim el-Kâtifî (ö. 945/1539'dan sonra) ${ }^{65}$ tarafindan eleştirilmiş olmasına rağmen Safevî İran'ında etkin bir konuma gelmiş ve Şiî ulemânın otoritesinin artmasının ve hatta müstakil bir güç haline gelmesinin önünü açmıştır. ${ }^{66}$

Şah Tahmasb'ın el-Kerekî'yi İran'a davet için yayınladığı fermanlarla birlikte onun siyâsî nüfûzunu gösteren bir diğer gelişme de sadr görevini üstlenen Mîr Gıyâseddin'le olan tartı̧̧masında şahın kendisini desteklemesidir. el-Kerekî ile Mîr Gıyâseddin arasında devam eden en önemli tartışma kıblenin tayini meselesidir. Gıyâseddin, kıblenin tayininin matematiksel hesaplamaları gerektiren bir mesele olduğunu iddia ederek bunu matematik ve astronomi bilenlerin yapması gerektiğini iddia etmektedir. el-Kerekî ise bu işin bizzat fakihler tarafından yapılması gerektiğini iddia etmekte ve kendi tespitleri doğrultusunda Safevî topraklarında câmilerin kıblelerinin değiştirilmesini istemektedir. ${ }^{67}$ Safevî sarayında bu konuyla ilgili yapılan tartışmada Şah Tahmasb, el-Kerekî'yi desteklemiştir. Tahmasb kendi tezki-

${ }^{63}$ Arjomand, "The Mujtahid of the Age and the Mulla-bashi", 81; Colin Paul Turner, "The rise of Twelver Shi' ite externalism in Safavid Iran and its consolidation under 'Allama Muhammad Baqir Majlisi (1037/1627-1110/1699)" (Doctoral thesis, Durham University, 1989), 119; Newman, "The Myth of the Clerical Migration", 78; Andrew J. Newman, Safavid Iran, Rebirth of a Persian Empire (London: I.B.Tauris, 2006), 24.

64 Cengiz Kallek, "Kerekî, Muhakkık-1 Sânî", Türkiye Diyanet Vakfi İslâm Ansiklopedisi (Ankara: TDV Yayınları, 2002), 25:280.

65 Newman, "The Myth of the Clerical Migration", 83-91; Stewart, "Notes on the Migration of Āmilī Scholars", 95-97.

66 Çelenk, Iran'da Şî̉liğin Seyri, 278.

67 Newman, "The Myth of the Clerical Migration", 99-100. 
resinde bu durumu şu şekilde dile getirmektedir: "Bu sırada Müctehidü'zzaman Şeyh Abdü'l-Âli ile Mir Glyâseddin Mansûr-i sadr arasında ilmî tartışmalar oldu. Müctehidü'z-zaman gâlip olup haklı olduğu halde onun içtihadına riayet etmediler ve işi inada döktüler. Bunun üzerine hakkı gözeterek içtihadı onun üzerine sabit kıldık. " ${ }^{68} \mathrm{Bu}$ tartışmanın akabinde Mîr Gıyâseddin sadr görevinden azledilmiş ve yerine 935/1529 y1lında sadr olarak Giyâseddîn'in yardımcıllğ̆na tayin edilen ${ }^{69}$ el-Kerekî’nin öğrencisi Nimetullah el-Hillî’yi (ö. 940/1534) tayin etmiştir. ${ }^{70}$ Ancak el-Hillî, el-Kerekî'nin desteğiyle sadr görevine getirilmiş olmasına rağmen Cuma namazı konusunda el-Kâtifî’nin görüşünü kabul edip onunla yazışmalarda bulunmuştur. Bu durumdan rahatsız olan el-Kerekî, siyâsî nüfûzunu kullanarak el-Hillı̂'yi de azlettirerek Bağdat'a sürgün ettirmiştir. ${ }^{71}$ Dolayısıyla bütün bunlar, onun siyâsî yönetimle olan ilişkisini ve Safevî İran'ında artan nüfûzunu açıkça ortaya koymaktadır. Diğer taraftan el-Kerekî, Safevî yönetiminde üstlendiği görevler ve devlete sağladığı meşruiyet sebebiyle Şah İsmâil ve Tahmasb tarafından çeşitli ihsanlara mazhar olmuş ve Irak bölgesindeki çok geniş arazileri ona soyurga $7^{72}$ olarak vermiştir. ${ }^{73}$

\subsection{Ali el-Kerekî Hakkında Yayınlanan Fermanlar}

Ali el-Kerekî hakkında yayınlanmış fermanlar, İmâmiyye mezhebini tercih etmiş Safevîler'in ulemânın gücüne ihtiyaç duyduklarının ve devlet içerisinde ulemânın otoritesinin güçlendiğinin resmini ortaya koymaktadır. ${ }^{74}$

68 Şah Tahmasb, Şah Tahmasb-ı Safevî Tezkire, çev. Hicabi Kırlangıç, 2. Baskı (Ankara: Atlas Kitap, 2015), 29.

69 Rumlu, Ahsenü t-tevârîh, 293.

70 Rumlu, 307; Arjomand, The Shadow of God, 136; Newman, "The Myth of the Clerical Migration", 97.

71 Rumlu, Ahsenü 't-tevârîh, 333-34.

72 Soyurgal, Yöneticinin önemli görevler üstlenen kişilere ihsanda bulunduğu topraklardır. $\mathrm{Ki}$ bu topraklar varislere intikal eder ve vergiden muaf tutulur. Bk. Kâzım Paydaş, "Moğol ve Türk-İslâm Devletlerinde Suyurgal Uygulaması", Bilig: Türk Dünyası Sosyal Bilimler Dergisi, no. 39 (2006): 195-218.

73 Mîrzâ Hüseyin en-Nûrî et-Ṭabersî, Hâtimetü'l-Müstedrek, c. 2 (Kum: Müessesetü Âl-i Beyt li-İhyâi't-Türâs, 1415), 284; el-İsbahânî, Riyâzü̈'l- 'ulemâ, 1401, 3:450; Turner, "The rise of Twelver Shi'ite externalism in Safavid Iran", 122.

74 Said Amir Arjomand, "Two Decrees of Shah Tahmasp Concerning Statecraft and the Authority of Shaykh 'Ali al-Karaki", Authority and Political Culture in Shi'ism, ed. Said Amir Arjomand (Albany: State University of New York, 1988), 250. 
el-Kerekî'nin dinî otoritesinin kabulü ve siyâsî iktidarın meşruiyet sahasını genişletme anlamına gelen 16 Zilhicce 939 tarihli ferman şu şekildedir:

"Ebedîlikle muttasll devletin [Safevîler'in] müjdelerinin belirmesinden, saadet ve yüksek gü̧̈ sancağının ortaya çıkmasından bu yana. Ki bu ikisine bağll kalınmazsa mutluluğa erişenlerin sahifesine yazılmaz. Zuhuruyla âlem ve âlemlerde cehaletin izlerinin ortadan kalkttğl şeriat-i nebeviyye-i ğarra'nin âlimlerinin makamlarının yüceltilmesinin saltanatın dayandı̆̆ ve üzerine hayır ve saadetin bina edildiği temel unsurlardan olduğunu biliyoruz. Seyyidü'l-mürselin'in şeriatının esasların ihya etmek ve muhaliflerin bid'at eserlerindeki zulmet tozlarını ortadan kaldlran aydınlık sabah gibi olan mâsum imamların-Allah'ın selamı onların üzerine olsun- gerçek yolunu ortaya çıkarmak için adalet güneşinin doğmast ve Sâhibü'l-emr' in dinini ikame etme şartına bağgl olduğu kabul ediyoruz.

Hiç şüphesiz din âlimlerine tâbi olmak ve onlara itaat etmek ve onların gittikleri yolda gitmek emniyete kavuşmanın esas ve amaca ulaşmanın dayanağıdır. Onları yardımları, dini yaymala$r l$, Seyyidü'l-mürselîn'nin şeriatını korumaları, yol göstermeleri ve irşad etmeleri vesilesiyle bütün insanlar dalâlet batakllğından hidâyet sahasina çıkabilmektedirler. Insanlardan her kim onların sözlerindeki berekete kavuşursa taklid ehli insanların zihinlerinde yer alan zulmet ve cehalet o kimseden kalkar. Özellikle [bu durum] feyiz ve yüce makam sahibi, masum imamların yolunun mütehassisl, hâtemü'l-müctehidîn rütbesine ulaşmış, Seyyidü'l-mürselîn'in ilimlerinin vârisi, Emîrü'l-mü'minîn'in dininin bekçisi, kurtuluşa erenlerin kıblesi, râsih âlimlerin örnegi i, hüccetü'l-İslâm ve müslimîn, insanları doğru dine sevk eden rehber, şeriatın ilkelerini açılklayan, zamaninin ileri gelenlerinin kabul ettiği, asrindaki bütün insanların iktida eylediği, helal ve haramı açıklayan, nâibü'l-İmâm, ismi gibi yüce olan zatınızın sahip olduğu kudsi kuvvetle gerçek hukuk ve din ehlinin esaslarındaki müşü̈lleri açılklğa kavuşturacaktır. Her bölge ve beldeden değerli ulemâ tevazu içerisinde yüce makamınızın eşiğinde boyun eğilmektedirler ve onlar [zât-ı âlinizin] müktesebatınızdakilerden istifade etmekle onurlandılar. Ayrica asrın önde gelenleri emir ve yasaklarınıza uymakta ve hidayet ve kurtuluşa ermenin hükümlerinize tâbi olmakla gerçekleşeceği kanaatindeler.

Zâtınızın makamını âli kalmak ve onu yüceltmek için [devletiminiz] himmeti ve kudsî niyetinin tamamın size hasrettik. Bunun temini için devletimizin tüm ileri gelenleri, yöneticileri, vezirleri ve diğer devlet erkânı, yukarı sıfatları zikredilen zât-ı âlinize tabi 
olmakta ve sizi imam kabul etmektedir. Bütün işlerde size itaat edeceklerdir. Emrettiğiniz yapılacak, nehy ettiğiniz yasaklanacaktır.

Memâlik-i mahrûse ve asâkir-i mansûredeki şer 'î işlerde görev vermiş olduklarınız tayin edilecek, görevine son verdikleriniz de azledilecektir. Yapmış olduğunuz bu tayin ve azillerde başka bir senede ihtiyaç duyulmayacaktır. Azletmiş olduğunuz hiçbir kimse zât-ı âlileriniz tarafindan tekrardan görev verilmediği sürece tekrardan atanmayacaktır Ayrica Necef nehri ile nehr-i cedîd arasında yer alan Kebîse ve Devâlîb bölgelerinin tarımsal arazileriyle... Ramahiye bölgesinin işlenmiş toprakları zât-ı âlileri ve nesli için şeriatın esasları doğrultusunda vakfedilmesinde karar verdik...

Şah Tahmasb 16 Zilhicce 939'75

$\mathrm{Bu}$ fermanın kenarında ise Şah Tahmasb'ın kendi hattıyla "yukarıda belirtilen hükümler ve insanların kendisine tabi olduğu kişi (mukteda'l-enâm) hakkında tüm emirler imzalanmıştır. Bu emirlerin hilâfina hareket edenler mürted ve melundur" ibaresi yer almaktadır. ${ }^{76}$

el-Kerekî'yi İran'a daveti konu edinen bir diğer ferman daha vardır. Ancak yukarıda verilen fermanın aksine burada bir tarih kaydı verilmemektedir. Sübhânî, fermanda bulunması gereken tarihi, büyük bir ihtima müstensihler kaydetmemiş olabileceğini iddia etmektedir. $\mathrm{O}$, yukarıda vermiş olduğumuz 16 Zilhicce 939 tarihli fermanda geçen ifadelerden hareketle bu fermanın hicrî 939 tarihinden önce muhtemelen de 936 yılında yazılmış olabileceğini kabul etmektedir. ${ }^{77}$ el-Kerekî̀ ye hitâben kaleme alınan bu ferman da şöyledir:

"Imam Sâdlk'a nispet edilen sahih bir hadiste şöyle buyurulur:

"Bizden hadis rivayet eden, helalimizi ve haramımızı araştıran ve hükümlerimizi bilen kimselere tabi olunuz. Onun verdiği hükme razı olunuz. Zira onları sizin üzerinize hâkim kildım. O bir hüküm verdiğine onun hükmünü kabul etmeyen kimse Allah'ın hükmünü hafife almış ve bizim hükmümüzü de reddetmiştir. $O$

75 TTabersî, Hâtimetü'l-Müstedrek, 2:282-90; el-İsbahânî, Riyâzü'l- 'ulemâ, 1401, 3:45560; el-Muhâcir, el-Hicretü'l-Âmiliyye ilâ Irân, 227-28; Newman, "The Myth of the Clerical Migration", 252-55; Çelenk, Iran'da Şiîliğin Seyri, 278.

76 İsbahânî, Riyâż̈'l- 'ulemâ, 1401, 3:360.

77 Ca'fer es-Sübhânî, el-Muhakkık el-Kerekî: Recülü'l-ilm ve’s-siyâse, (Kum: Müessesetü'l-İmâm es-Ṣâdık, 1382), 109. 
Allah'a karşı gelmiş olur ve şirk sınırındadır. ${ }^{78}$ Bu hadise göre Seyyidü'l-mürselîn'in şeriatının koruyucuları olan müctehidlerin hükümlerine muhalefet etmek şirk mesabesindedir. Bundan dolayı hâtemü'l-müctehidîn, Seyyidü'l-mürselînin ilimlerinin vârisi, Mâsum İmâm 'ın [Mehdî el-Muntazar] nâibi (nâibü'l-İmâm) ismi gibi yüce olan [Ali el-Kerekî'ye] muhâlefet eden ve ona tabi olmayan hiç şüphesiz merdud kabul edilip bulunduğu görevlerden uzaklaştırılacaktır. Böyle birisi ciddi tedbirler alınacak ve şiddetli cezalar uygulanacaktır. Tahmasb b. Şâh İsmâil es-Safevî el-Mûsevî." "79

İran'da din-devlet ilişkilerini yeniden düzenleyen bu fermanlar, Mîr Nimetullah el-Hillî’nin sadr görevinden azledilip el-Kâtifî ile irtibata geçmesinin yasaklanmasından kısa bir süre sonra yayınlanmıştır. ${ }^{80}$ Fermanlarda el-Kerekî'nin fikhî konumuna açık bir şekilde vurgu yapılmakta ve ona "yarı resmî bir statü" “hâtemü'l-müctehidîn, Seyyidü'l-mürselînin ilimlerinin vârisi, nâibü'lİmâm, mukteda'l-enâm, helal ve haramları açıklayan gibi sıfatlarla nitelendirilmekte ve onun fikhî konumuna vurgu yapılmaktadır. ${ }^{82}$ Söz konusu nitelendirilmeler, toplumsal dönüşüm sürecinde siyâsî iktidarın meşruiyet sahasını genişletmek için ulemânın desteğine ihtiyaç duyduğunun bir göstergesidir. Nitekim fermanlarda bütün devlet erkânının el-Kerekî’ye itaat edeceği açıça belirtilmektedir. Ayrıca onun herhangi bir kişiyi bir göreve tayin etmesi ve veya bulunduğu makamdan azletmesi için başka bir emrin gerekli olmadığına vurgu yapılmaktadır. Hatta fermanla Irak topraklarındaki büyük arazilerin soyurgal olarak verilmiş olması bunun açık delilidir.

Bununla birlikte kanaatimize göre fermanda el-Kerekî’yle ilgili en önemli iki nitelendirme, mukteda 'l-enâm ve nâibü'l-İmâm makamıdır. Mukteda'lenâm vasfiyla el-Kerekî, sadece âlimlerin tâbi olduğu değil aynı zamanda

\footnotetext{
78 Sikâtü'l-İ̀slâm Muhammed b. Ya 'ḳûb el-Kuleynî, el-Kâfí fì ilmi'd-dîn, 3. Bask1, c. 7 (Tahran: Dârü'l-Kitâbi'l-İslâmiyye, 1367), 412.

79 Muhâcir, el-Hicretü'l-Âmiliyye ilâ Irân, 126, 226; el-Kâtib, Şiada siyasal düşüncenin gelişimi, 431.

80 Ann K. S. Lambton, State and Government in Medieval Islam, An Introduction to the Study of Islamic Political Theory: The Jurists, ; (Oxford: Oxford University Press, 1981), 277; Arjomand, "The Mujtahid of the Age and the Mulla-bashi", 81.

81 Uyar, Ulemanin Otoritesi, 126.

82 Arjomand, "The Mujtahid of the Age and the Mulla-bashi”, 81.
} 
Safevî toplumunda herkesin rehberi olduğu kabul edilmektedir. ${ }^{83}$ Siyâsî iktidar tarafindan böyle bir desteğe kavuşan el-Kerekî ve ardından onun takipçileri, Safevî İran'ında İmâmiyye mezhebinin yerleşmesini sağladılar. On yedinci yüzyılın başlarından itibaren de politik bir güç haline geldiler. ${ }^{84}$

Fermanda el-Kerekî' nin “Gâib İmâm'ın temsilci (nâibü'l-imâm)” olduğuna vurgu yapılması bir diğer önemli noktadır. Zira o, âlimin rolüne vurgu yapan usûlî geleneğe mensuptur. Dolayısıyla siyâsî otoriteyle ilişki kuran müctehidin Gâib İmam'ın temsilcisi olduğunun ifade edilmesi, bir anlamda Safevî yönetiminin onaylanması anlamına gelmektedir. ${ }^{85}$ Bu bağlamda el-Kerekî'nin özellikle haraç, Cuma namazı ve sebbü's-sahabe konularında vermiş olduğu fetvalar, Şiî siyaset düşüncesine göre câir yönetim olarak kabul edilmesi gereken Safevî yönetiminin onaylanması anlamına gelmektedir. Bu sebeple nâibü'l-imâm olarak nitelendirilen el-Kerekî, verdiği fetvalarla esâsen Safevî iktidarının hareket sahasını genişletmekte, siyâsî gücün ulemâ tarafindan da desteklenmesinin yolunu açmaktadır. ${ }^{86}$

\section{Sonuç}

İslam dünyasının çeşitli bölgelerinde kurulan hanedanlıklar, çeşitli sebeplerle ilim ehlinin kendi topraklarına gelmelerini teşvik etmişlerdir. Yöneticilerin ilim ehlini davet etmelerinin ve hatta onlar hakkında fermanlar göndermelerinin sebeplerinden biri de hanedanlığın mezhebî tercihidir. Bunun önemli bir örneğini de uzun süre Sünnî yönetimlerin kontrolünde olan İran coğrafyasında kurulan Serbedârîler (1337-1386) ve Safevîler (1501-1736) oluşturmaktadır. Bu bağlamda dinî ve siyâsî gerekçelerle Serbedârî Emîri Ali el-Müeyyed, Şehîd-i Evvel'i; Safevî hükümdarı Şah Tahmasb ise Ali el-Kerekî’yi kendi topraklarına davet etmişlerdir.

Serbedârîlerin ortaya çıkışı ve devletleşmesinde dönemin siyâsî ve ekonomik şartları kadar imâmet ve mehdilik anlayışları da etkili olmuştur.

\footnotetext{
83 Uyar, Ulemanın Otoritesi, 126.

84 Arjomand, "The Mujtahid of the Age and the Mulla-bashi”, 82; Çelenk, Iran'da Şî̀liğin Seyri, 278.

85 Hourani, "From Jabal 'Amil to Persia”, 137; Arjomand, The Shadow of God, 133-34; Newman, Safavid Iran, 24.

86 Mehmet Çelenk, "Safevîlerin Din Politikası ve İran'ın Şiîleşme Seyri”, Çanakkale Onsekiz Mart Üniversitesi İlahiyat Fakültesi Dergisi, no. 4 (2014): 28.
} 
Serbedârîlerin mezhebi kimliğinde en önemli unsuru Şiîlik oluşturmaktadır. Nitekim Ali el-Müeyyed'in rasyonel İmâmî anlayışı hâkim kılmak için Şehîd-i Evvel-i davet etmesi, Gaib İmam gelişi için bir atın hazır bulundurulması ve On iki imam adına sikke bastırılması bunun delili niteliğindedir. Şehîd-i Evvel'in Serbedârî topraklarına davet edilmesinde iki önemli gerekçe bulunmaktadır. Bunlar rasyonel İmâmî fikhını topluma hâkim kılmak ve Ali el-Müeyyed'in Şeyh Hasan el-Cûrî taraftarlarını tamamen bertaraf etmek istemesidir. Şehîd-i Evvel'e mektup, büyük bir ihtimalle Emîr Timur'un Serbedârî merkezi Sebzevar'1 tamamen ele geçirdiği 784/1383 tarihinden önce ve Ali el-Müeyyed'in Derviş Rukneddin isyanının bastırıldığ 1 780/1379 tarihinden bir süre sonra gönderilmiştir. Söz konusu mektuba Şehîd-i Evvel'in olumlu cevap vermemesinin gerekçesi açık değildir.

Mezhebî tercih bağlamında İran tarihinde en önemli kırılma, Safevîlerin İmâmiyye'yi devletin resmi mezhebi olarak kabul etmesidir. Safevîler, toplumsal dönüşümde kendilerine yardımcı olmaları için bölge dışındaki İmâmî ulemâya ihtiyaç duymuş ve Cebel-i Âmil bölgesindeki İmâmî ulemâyı İran'a davet etmişlerdir. Safevîler yeni bir ilmiye sınıfı oluşturmak için zorunlu olarak bölge dışındaki İmâmî ulemâya başvurmuşlardır. Bir diğer önemli gerekçe de siyâsî iktidarın meşruiyet sahasını genişletmek için içtihadı esas kabul eden ulemânın desteğine ihtiyaç duymasıdır.

el-Kerekî, Cebel-i Âmil ulemâsıyla Safevî yönetimi arasında kurulan ilişkide önemli bir yere sahiptir. Safevî yönetiminde bazı önemli görevler üstlene n el-Kerekî, Safevî kimliğinin oluşması ve devlete meşruiyet kazandırma sürecinin parçası olmuştur. Şah Tahmasb'ın onun hakkında fermanlar yayınlaması, Safevîler'in ulemânın gücüne ihtiyaç duyduklar1nın açık bir göstergesidir. Sonuç olarak siyâsî istikrara kavuşan Safevîler, yayınladıkları fermanlar ve ulemâya sağladıkları imkânlarla İran topraklarında İmâmiyye mezhebinin yerleşmesini sağlamışlardır.

\section{Kaynakça}

Abisaab, Rula Jurdi. "History and Self-Image: The Amilis and Their Clerics in Syria and Iran (Fourteenth to Sixteenth Centuries)". Distant Relations: Iran and Lebanon in the Last 500 Years, editör H. E. Chehabi, 62-95. London: I.B.Tauris, 2006.

Abisaab, Rula Jurdi. "The Ulama of Jabal "Amil in Safavid Iran, 15011736: Marginality, Migration and Social Change”. Iranian Studies 27, no. 1 (1994): 103-122. 
Ahmetoğlu, Şahin. "Serbedârî Hareketi ve Temel Görüşleri”. e-Makalat Mezhep Araştırmaları Dergisi 7, no. 1 (2014): 129-54.

Ajend, Yakûb. Ķıŷm-ı Şi î Serbedârân. Tahran: Neşr-i Göstere, 1363.

Âmilî, Muhammed b. Hasan el-Hür el-. Emelü'l-Âmil. C. 1. 2 c. Bag̉dât: Mektebetü'l-Endülüs, ts.

Arjomand, Said Amir. "The Mujtahid of the Age and the Mulla-bashi: An Intermediate Stage in the Institutionalization of Religious Authority in Shi' ite Iran". Authority and Political Culture in Shi'ism, editör Said Amir Arjomand, 80-97. Albany: State University of New York, 1988.

Arjomand, Said Amir. The Shadow of God and The Hidden Imam. Chicago: The University of Chicago Press, 1984.

Arjomand, Said Amir. "Two Decrees of Shah Tahmasp Concerning Statecraft and the Authority of Shaykh 'Ali al-Karaki". Authority and Political Culture in Shi 'ism, editör Said Amir Arjomand, 250-62. Albany: State University of New York, 1988.

Aştiyânî, Abbas İkbal. Târîh-i Moġol Ez Hamle-yi Çingîz tâ Teşkîl-i Devlet-i Tîmûrî. Tahran: Müessese-i İntişârât-1 Emîr Kebîr, 1384.

Aubin, J. "Sāh Ismāil et Les Notables de l'Iraq Persan". Journal of the Economic and Social History of the Orient 2, no. 1 (1959): 37-81.

Baḥrânî, Yûsuf b. Aḥmed el-. Lü'lüetü'l-bahreyn fi'l-icâzât ve terâcimü ricâli'l-ḥadîs. Bahreyn: Mektebetü'l-Fahravî, 1429.

Battûta, Ebû Abdullah Şemseddin Muhammed b. Abdullah İbn. İbn Battûta Seyahatnâmesi. Çeviren A. Sait Aykut. C. 1.2 c. İstanbul: Yapı Kredi Yayınları, 2004.

Browne, Edward Granwille. A Literary History of Persia. 5. Bask1. C. 4. 4 c. Cambridge: The Cambridge University Press, 1959.

Büchner, V. F. "Serbedârîler". MEB İslam Ansiklopedisi, 10:509-12. İstanbul: Milli Eğitim Basımevi, 1988.

Cáferiyân, Resul. Târîh-i teşeyyú der Iran: ez ăgaz tâ țulûu devleti Ṣafevî. 4. Baskı. Tahran: Neşr-i İlm, 1390.

Coşkun, Derya. "Serbedârî Devletinin Siyasî, İçtimaî ve İktisadî Tarihi (1336-1382)". Doktora Tezi, Atatürk Üniversitesi, 2016. 
Coşkun, Derya. 'XIV. Yüzyıl Horasan'ında Şiî Bir Otorite: Şeyh Hasan Cevrî ve Siyaset Algısı". Türk Kültürü ve Hacı Bektaş Veli Araştırma Dergisi, no. 90 (2019): 65-76.

Çavuşoğlu, Ali Hakan. "Şehîd-i Evvel”. Türkiye Diyanet Vakfi İslâm Ansiklopedisi, 38:437-40. İstanbul: TDV Yayınlar1, 2010.

Çelenk, Mehmet. 16-17. Yüzyıllarda İran'da Şiîliğin Seyri. 2. Bask1. Bursa: Emin Yayınları, 2016.

Çelenk, Mehmet. "Safevîlerin Din Politikası ve İran'ın Şiîleşme Seyri”. Çanakkale Onsekiz Mart Üniversitesi Illahiyat Fakültesi Dergisi, no. 4 (2014): 7-35.

Demir, Habip. Horasan'da Şiilik: Irran'da Şiiliğin Tarihsel Kökleri. Ankara: OTTO, 2017.

Emânî, Muhammed Ḥüseyin el-. eş-Şehîdü'l-Evvel: Fakîhü̈s-Serbedârân. Çeviren Kemâl es-Seyyîd. Kum: Müessese-i Enșâriyân, 1415/1995.

Güner, Ahmet. "Büveyhî Devlet Adamlarının Kitaba İlgileri ve Kütüphaneleri”. Dokuz Eylül Üniversitesi Illahiyat Fakültesi Dergisi, no. 13 (2001): $35-63$.

Güner, Ahmet. "Sâbûr b. Erdeşîr ve Dâru'l-İlm'i”. Dokuz Eylül Üniversitesi Illahiyat Fakültesi Dergisi, no. 13 (2001): 65-92.

Ḥamd-Allah Mustawfi Ḳazvînî. Nuzhat-al-Kulûb. Çeviren G. Le Strang. London: Brill, 1919.

Ḩândmir, Ġyâseddîn b. Hümâmiddîn Hüseynî. Târîhu habîbi s'siyer $f i$ ahbâri efrâdi beşer. C. 3.4 c. Tahran: Kitabḥâne-i Hayyâm, 1333.

Hourani, Albert. "From Jabal 'Amil to Persia". Bulletin of the School of Oriental and African Studies, no. 49 (1986): 133-40.

İbni Arabşah. Acaibu'l Makdur (Bozkırdan Gelen Bela). Çeviren Ahsen Batur. İstanbul: Selenge Yayınları, 2012.

İbn Miskeveyh, Ebû Ali Aḥmed b. Muḥammed b. Yákûub. el-Kısmu'l-ahîr min kitâbi Tecâribi'l-ümem. C. 2. 2 c. Oxford: Basil Blackwell, 1921.

İsbahânî, Mirza Abdullah Efendi. Riyâzzü'l- 'ulemâ ve hiyyâzü̉'l-fudelâ. C. 5. 6 c. Kum: Matba'atü’l-Hayyâm, 1401. 
İsbahânî, Mirza Abdullah Efendi.. Riyâzzü'l-'ulemâ ve hiyâazü'l-fựelâ. C. 3. 6 c. Kum: Matba'atü'l-Huayyâm, 1401.

İṣbahânî, Mîrza Abdullah Efendi el-. Tálîkatü Emeli’l-âmil. Mektebetü Ayetullah el-Mar'aşi, 1410.

Kallek, Cengiz. "Kerekî, Muhakkık-1 Sânî". Türkiye Diyanet Vakfi İslâm Ansiklopedisi, 25:280-82. Ankara: TDV Yayınları, 2002.

Kartaloğlu, Habib. "Batılı Araştırmacılara Göre Safevi İran'a Şiî Ulemâ Göçü”. Turkish Journal of Shiite Studies 1, no. 1 (2019): 25-48.

Kâtib, Aḥmed el-. Şiada Siyasal Düşüncenin Gelişimi. Çeviren Mehmet Yolcu. Ankara: Kitâbiyât, 2005.

Kazvinî, Abdülcelîl el-. Kitâbü'n-Nakd: Ba 'du mesiâlibi'n-nevâșib fí nakdi ba 'du feḍ̂ihi'r-revâfiż. Tahran: Encümeni Așânı Millî, 1358.

Konukçu, Enver. "Beyhak”. Türkiye Diyanet Vakfi İslâm Ansiklopedisi, 6:57-58. İstanbul: TDV Yayınlar1, 1992.

Kuleynî, Sikâtü'l-İ̀slâm Muḥammed b. Ya'kûub el-. el-Kâfí fî ilmi'd-dîn. 3. Bask1. C. 7.8 c. Tahran: Dârü'l-Kitâbi'l-İslâmiyye, 1367.

Lambton, Ann K. S. State and Government in Medieval Islam, An Introduction to the Study of Islamic Political Theory: The Jurists. ; Oxford: Oxford University Press, 1981.

Mahendrarajah, Shivan. "The Sarbadars of Sabzavar: Re-Examining Their 'Shi'a' Roots and Alleged Goal to 'Destroy Khurasanian Sunnism". Journal of Shi' 'a Islamic Studies 5, no. 4 (2012): 379-402.

Mazzaoui, Michel M. The Origins of the Safawids: Shi 'ism, Sufism and the Ghulat. Wiesbaden: Franz Steiner Verlag, 1972.

Meclîsî, Muhammed Bâḳ̂r el-. Bihâarü'l-envâr li düreri ahbâri'l-eimmeti'lethâr. 2. Bask1. C. 104. 110 c. Beyrût: Müessetü'l-Vefâ, 1983.

Merçil, Erdoğan. "Serbedârîler”. Türkiye Diyanet Vakfi İslâm Ansiklopedisi, 36:549-50. İstanbul: TDV Yayınları, 2009.

Mîrhând, Seyyid Ḥamidüddin Muhamammed b. Burhaneddin Hुandşah b. Kemaleddin. Târîh-i Ravżatü 's-șafâ fì sîreti'l-enbiyâ ve'l-mülûk ve'l-hnulefâ. C. 5.7 c. Tahran: Müessese-i Hayyâm ve İntişarât-1 Pîruz, t.s. 
Momen, Moojan. An Introduction to Shii Islam. New Haven and London: Yale University Press, 1985.

Muhâcir, Cafer. el-Hicretü'l-Âmiliyye ilâ İrân fi'l-aṣri's-Ṣafevî. Beyrût: Dârü’r-Raḍ̂â, 1989.

Münferid, Mehdî Ferhâni. Muhâceret-i ulemâ-yı Şı̂a ez Cebel-i Âmil be Iran Der Aṣr-ı Ṣafevi. Tahran: Müessese-i İntişârât-1 Emîr Kebîr, 1396.

Newman, Andrew J. Safavid Iran, Rebirth of a Persian Empire. London: I.B.Tauris, 2006.

Newman, Andrew J. "The Myth of the Clerical Migration to Safavid Iran". Die Welt des Islams, no. 33 (1993): 66-112.

Paydaş, Kâzım. "Moğol ve Türk-İslâm Devletlerinde Suyurgal Uygulamas1". Bilig: Türk Dünyast Sosyal Bilimler Dergisi, no. 39 (2006): 195-218.

Perhizkârî, Seyyid Ruhullah. "Naksşi Devlet-i Şî‘a Serbedârân-1 Horasân Der Göstereş-i Teşeyyu“ ve Temeddün-i İslâmî”. Pejûheşi Tarîh-i Ferheng ve Temeddün-i İslâmî 4, no. 13 (2014): 31-50.

Roemer, H. R. "The Jalayirids, Muzaffarids and Sarbadars". The Cambridge History of Iran, editör Peter Jackson ve Lawrence Lockhart, 6:1-42. Cambridge: Cambridge University Press, 1986.

Rumlu, Hasan Beg. Ahsenü 't-tevârîh. Tahran: Çâbhâne Haydarî, 1357.

Smith, John Masson. The History of the Sarbadâr Dynasty 1336-1381 A.D. And Its Sources. The Hague/Paris: Mouton, 1970.

Stewart, Devin J. "Notes on the Migration of Āmilī Scholars to Safavid Iran". Journal of Near Eastern Studies 55, no. 2 (1996): 81-103.

Sübhânî, Ca'fer. el-Muhakkık el-Kerekî: Recülü'l-ilm ve's-siyâse,. Kum: Müessesetü'l-İmâm es-Șâdık, 1382.

Sümer, Faruk. Safevi Devletinin Kuruluşu ve Gelişmesinde Anadolu Türkleri. Ankara: Selçuklu Tarih ve Medeniyeti Enstitüsü Yayınları, 1976.

Şah Tahmasb. Şah Tahmasb-ı Safevî Tezkire. Çeviren Hicabi Kırlangıç. 2. Bask1. Ankara: Atlas Kitap, 2015.

Şahin, Hanifi. Illhanlılar Döneminde Şiilik. İstanbul: Ötüken Neşriyat, 2010. 
Şahin, Mustafa. Serbedârîler Darağacının Gölgesinde Kurulan Bir Devlet. İstanbul: İdeal Kültür Yayınc1lık, 2017.

Şehîd-i Sânî, Zeynüddîn b. Ali el-Âmilî. er-Ravżatü'l-behiyye fî̀ şerhi Lüm 'ati'd-Dımaşkıyye. 2. Baslı. C. 1.10 c. Kum: Çâbhâne-i Emîr, 1398.

Ṭabersî, Mîrzâ Hüseyin en-Nûrî. Hâtimetü'l-Müstedrek. C. 2. 6 c. Kum: Müessesetü Âl-i Beyt li-İhyâi’t-Türâs, 1415.

Turner, Colin Paul. "The rise of Twelver Shi'ite externalism in Safavid Iran and its consolidation under 'Allama Muhammad Baqir Majlisi (1037/1627-1110/1699)". Doctoral thesis, Durham University, 1989.

Tüsterî, Kâḍ̂i Nûrullah el-Mer'aşî. Mecâlisü'l-mü'minîn. C. 3.4 c. b. y.: Dârü Hişâm, 1439/2017.

Uyar, Mazlum. Şiî Ulemanın Otoritesinin Temelleri. İstanbul: Kaknüs Yayınları, 2004.

Winter, Stefan. "Shams al-Din Muhammad ibn Makki 'al-Shahid alAwwal' (d. 1384) and the Shi'ah of Syria". Mamluk Studies Review 3 (1999): 149-82.

Yuvalı, Abdülkadir. "Ebû Said Bahadır Han". Türkiye Diyanet Vakfı İslâm Ansiklopedisi, 10:218-19. İstanbul: TDV Yayınları, 1994. 